\title{
Sport Events Customers' Behavior in the Light of Hedonic Consumption
}

\author{
Daniel Adrian Gârdan ${ }^{1}$, Iuliana Petronela Gârdan ${ }^{1}$, Mihai Andronie ${ }^{1}$ \& Ionel Dumitru ${ }^{2}$ \\ ${ }^{1}$ Department of Economic Science, Spiru Haret University, Bucharest, Romania \\ ${ }^{2}$ Department of Marketing, Bucharest University of Economic Studies, Romania \\ Correspondence: Iuliana Petronela Gârdan, Department of Economic Science, Spiru Haret University, Bucharest, \\ Romania. E-mail: geangupetronela@yahoo.com
}

\author{
Received: April 17, $2020 \quad$ Accepted: May 25, $2020 \quad$ Online Published: June 23, 2020 \\ doi:10.5539/ijms.v12n3p26 URL: https://doi.org/10.5539/ijms.v12n3p26
}

\begin{abstract}
Consumption of sport events has raised the specialists' interest since it has become a global phenomenon, accessible to a large mass of consumers. At the same time, this consumption generates implications from an economic, social, and cultural point of view, in the countries/locations where various sport events have been organized, through the development of cultural and sport tourism. Sport event consumption belongs to the category of consumption acts that presume total implication apart from individuals and accordingly, their emotional involvement. This involvement is correlated on the one hand with the typology and the nature of needs and consumption motives underlying this consumption, and on the other hand with the more and more intensive promotion of these events and the easier participation access of consumers. Consumer involvement is a multidimensional construct, so the idea of an "involvement profile" is more appropriate to describe how the consumer relates to such products or services. The purpose of our paper is to clarify whether involvement within consumption for sport events customers is determining a specific behavior for the hedonic type of consumption also related to other categories of products or services. The consumption of sport events represents mainly a hedonic type of consumption correlated with a high level of emotional involvement during the consumption process, an involvement developed against the backdrop of the special role, and specific meaning that sport events can have at the level of individuals' perception.
\end{abstract}

Keywords: customer involvement, hedonic consumption, utilitarian consumption, emotions

\section{Introduction}

In the context of the increasing popularity of sports events that involve numerous participants, their economic impact has become an interesting topic for researchers in a multitude of scientific domains, among which we can mention psychology, marketing, urban planning, etc. The consumption of sporting events involves the existence of a background suitable for an intense experience. The effort to appraise the experiences lived by events consumers has led to an attempt to measure the level and intensity of their emotional involvement (Geus et al., 2016; Zatori et al., 2018). Recent research highlights that there is a direct link between emotional responses and behavioral intentions of customers (Prayag et al., 2017). Knowing how consumers are developing their emotions and involvement could help to predict the behavior in terms of intentions and preferences. In terms of hedonic type consumption, the self-actualized emotional state has tremendous importance regarding consumption decisions (Albrecht et al., 2016; Huber et al., 2018). In this context, advanced data analysis techniques may be used on big data sets related to sports events consumption. Still, there is no clear opinion regarding the possibility that due to the strong emotional involvement during sport event manifestation, consumers may show a hedonic type consumption also oriented towards different goods like products related to the event itself (t-shirts, mugs, badges, etc.) or other products or services related to the location of the event (city, region, etc.).

Our endeavor is meant as a contribution to the academic discussion regarding the relationship between the involvement of sports events consumers and their purchase decisions to clarify whether their involvement in sport events is determining a hedonic type of consumption behavior. We consider that sport events consumers are achieving a particular state of mind during the events consumption, in which hedonic motives are preeminent and the consumption behavior presumes buying decisional processes related to various products and services complementary or not to the event itself. Our paper aims to reveal the importance of hedonic consumption in the 
context of sport events, with a focus on buying behavior towards other products and services apart events. We believe that the mood gained during sports events predisposes participants to hedonic buying and consumption behavior, with important implications from the perspective of the development of sport and cultural tourism, the economic growth of the areas targeted and the adaptation of the local supply of products and services to the needs expressed by consumers.

\section{Motivation for Sport Event Attendance}

The psychological state, specific to consumer involvement is built on the broader framework based on consumer motivation. Motivation along with other psychological constructs is used as antecedents for involvement, motivation being one of the most important ones (Morris et al., 2018).

From the perspective of sports consumer behavior, the socio-psychological dimension of the motivation comprises two major perspectives: a certain persistent behavior that implies choices and the effect of these active, conscious choices in the form of an output variable as a factor that manifests itself at the individual level, leading to a series of acts in the form of events that crystallize as a behavior. Different individuals have various motivational characteristics that differ on criterion measures of concern regarding interest, attitudes, behavior, etc. A pretty large number of theories have been proposed to explain how sport events consumers are developing behavior. Still, empirical evidence is rather undeveloped. The main analyzed areas refer to individual motives and identification.

Among factors that have been pointed out, we may consider consumption satisfaction, involvement, commitment, marketing strategy, entertainment, support for players' league, quality of play, players themselves, players serving as models, entertainment value associated with games, beneficial environment, traditional style of play (Kirkup \& Sutherland, 2017).

Traditionally, the consumption motives of sport events spectators are based on hedonic principles, but several new factors have also been discovered that are dependent on a utilitarian perspective-like providing positive models for youth and promoting equal rights in sports. The effort made to have a better understanding of sports events consumption has implied the development of a model of analysis called: The Sport Interest Inventory-SII. The model works with 30 items assessing 10 motives regarding spectators' attendance to sport events: drama, vicarious achievement (seen as the need of a person to have a social prestige position, higher self-esteem and a sense of empowerment through affiliation with a sport team), aesthetics, the interest shown in connection with the team, certain individual players, the game itself, the manifestation of national pride feeling, excitement, perceived social opportunities, and in some cases, even support for women opportunities (Ga-Bin \& Hyung, 2018; Funk et al., 2002). Later were added into the model: the model image of certain players, the perceived degree of higher bonding with other family members, the beneficial environment of the games, entertainment value.

\section{Customers Involvement Dimensions}

When it comes to analyzing the complexity of the term involvement, it becomes obvious that it cannot be similar to a single dimension, even if it is about the "perceived importance" concept. Involvement is a concept that has many facets, necessary to overcome the different angles of approach specific to each individual (Laurent \& Kapferer, 1985). Many other scholars (Chang \& Gibson, 2015; Dwivedi, 2015; Kim et al., 2015; Seabra et al., 2016; Pansari \& Kumar, 2017) substantiates the complexity of customers' involvement concept and its multidimensional nature. There is a need to take into consideration multiple indicators to satisfactory analyze or even predict customers' involvement. From this perspective, the need to build a "profile of involvement" has naturally developed when analyzing the nature of the relationship that consumers have with the products/services consumed. Historically, the involvement concept was introduced by Sherif and Hoveland more than half a century ago. More researches were later developed during the 1980s to better explain purchase behavior related to consumer goods (Hong, 2015; Nyadzayo \& Khajehzadeh, 2016; Laud \& Karpen, 2017). From a psychological point of view, the involvement is associated with a motivational state which involves the explicit manifestation of interest, or attraction towards a product/service, activity, or object (Nisar et al., 2018). Subsequent studies have confirmed the approach of involvement from the perspective of the state of motivation that manifests in the conditions of the existence of a stimulus or situations that coagulate both the perception and the interest of individuals (Brown et al., 2016; Inoue et al., 2017; Kirkup \& Sutherland, 2017).

In the recreational environment that is much closer to the sport events situation, it has been concluded that three factors are significant: attraction, self-expression, and centrality (Tachis \& Tzetzis, 2015; Funk et al., 2016). The current view in scientific literature implies that attraction is a combination of two dimensions that have been previously analyzed separately: the degree of importance given by the consumer to the involvement in a certain 
activity (service) or to a certain product and the hedonic value or pleasure that can be attached to them. Self-expression is considered to be a message that can be communicated to consumers at a specific moment, and this information is directly related to the action/service or product under consideration (e.g., identified as a sports team fan) (Rocha \& Gratao, 2018). The centrality will take into account the dimension that expresses the degree of congruence between the individual's scale of values and the role played by a certain activity in his life, an identifiable role especially from a social perspective, based on the construction and development of relationships with acquaintances, friends or family (such as the opportunity to socialize at a game). People's behavior is affected by the fluctuations that may manifest over time regarding the evolution of their involvement profile (Chung et al., 2018). The consumption of sports events or the time when these services are consumed implies the manifestation of a variety of stimuli or situations that are a direct consequence of the different attributes that characterize the events in question, and which lead to changes in the situational involvement (Cheng et al., 2015).

The antecedents of involvement can be grouped into two broad categories: specific characteristics of individuals and social factors determined by the specific contexts in which they were involved (Hodges et al., 2016). Individual characteristics can refer to attitudes, values, motivations, needs, preferences, or different forms of consumer experiences. The second category, about specific social factors in a given situation, may include outcome rewards, the embodiment of social or cultural norms, pressures from interpersonal relationships, and various expected social benefits (Gârdan \& Gârdan, 2015).

In the opinion of the specialists, from the theoretic point of view, the involvement is associated with a variable differentiated at an individual level, a variable of causal and motivational nature. The consequences of the involvement at the level of purchasing behavior and the communication one, are taken into account the appearance and manifestation of differences over the stages of the purchasing decision process or in people's processing of communications (Singh et al., 2017; Teng \& Lu, 2016; Alonso-Dos-Santos et al., 2016; Zucco et al., 2015).

From the perspective of the relationship between products or services and consumer occasions, two forms of involvement have been considered in the scientific literature: enduring involvement and situational involvement (Chun \& Lee, 2016; Ko et al., 2017; Zatori et al., 2018). The situational involvement stands for a certain buying occasion or a choice made by the consumer, being more powerful when the consumer is perceiving risk in a specific situation, while the other pertains to an entire class of products having a permanent character (Whang et al., 2016; Cheng et al., 2016; Pan et al., 2018). This particularity stems from the fact that the enduring involvement is manifested in the conditions in which the products or services in question are in full agreement, representative, for the ego, personality, and fundamental values of a person (Forgas-Coll et al., 2017; Sato et al., 2018).

Another differentiation can be made from the perspective of the degree of emotion manifestation. This is why we talk about emotional involvement and rational involvement. In case of rational involvement, the consumer is worried about the cost-benefit ratio optimization so the pleasure is not present, the individual does not show any emotion or interest in a particular product category (Mutz \& Gerke, 2018). In case that the consumer has a degree of emotion associated with the involvement, the term "ego involvement" is used to highlight the personal nature of involvement (Park et al., 2015).

For the involvement to be manifested, it is necessary to first emphasize a series of antecedents that can refer to elements such as the connection between the status of a person and the symbolism attached to a product, the personal meaning attached to this product, its importance from the perspective of motivation consumption, the public position displayed by consumers, the strong influence exerted by a certain social situation in which the person can be found (Fenton et al., 2016; Walther et al., 2018).

Usually, a high degree of involvement (at least of a rational type) is associated with durable goods, because their purchase is accompanied by the risk that in the case of a mistake made by the consumer, he will be forced to keep a product that he considers inappropriate (Jun \& Park, 2016). Some of these goods can be also considered the object of an ego-involving type of involvement because they have a high degree of symbolic meaning (Shank \& Lulham, 2017). Also, a high degree of involvement of an emotional type can be associated with services in general as it is obvious that in case of services' consumption, we talk about a co-creation process, therefore the consumer is taking part to the process of production/delivery of the service and tend to appreciate the quality of the service from the point of view of human interaction.

Thus, it is important to know the involvement source, level, and development mechanism. Laurent and Kapferer stated that involvement can have 5 facets or antecedents: product perceived importance, product purchase 
perceived risk (the importance given to the choice of an inadequate product), the symbolic value of the product and hedonic value of the product (ability to provide pleasure/affect) (Harrigan et al., 2018).

When considering the interests of consumers towards certain products or services other variables can be taken into account and considered relevant: the degree of extension usually associated with the information seeking and choice process. Other studies suggest other relevant variables: consumption alternatives, perceived differences, and price. The perceived difference can stimulate on a large scale the choice and search behavior (Rajala et al., 2015). When the level of price is high, consumers spend more time searching for information and choosing (Jun \& Park, 2016; Raposo et al., 2018).

\section{Propensity Over Hedonic Consumption During Sport Events Attendance}

In the case of consumers that are searching for different ways to reduce risks associated with purchasing goods or services, the utilitarian consumption represents a relevant attitude that is dealing with experiences that can be measured and have an important tangible dimension (Gerhard et al., 2017).

More than a century ago, Veblen has coined the conspicuous consumption concept (Huang \& Wang, 2018), but it was not until the 1980s that the emotional characteristics behind consumption were explored (Zheng et al., 2018) The hedonic purchase type implies a specific consumer's perception considering the object of purchase being a subjective symbol, strongly correlated with the desire felt by the individual and associated with an easy task to perform (Shank \& Lulham, 2017; Epuran et al., 2015; Vegheș, 2018). The hedonic type consumption is influenced by the perception of the intrinsic value of the purchasing object completed by the direct influence of subjective factors. These influences will also take into account the sensibilities of each individual. There is plenty of proof within scientific literature that the two different types of consumption — utilitarian and hedonic can merge within a single buying experience and do not exclude each other (Marriott et al., 2017; Hossain, 2018). In the majority of cases, the main consumption reason is a utilitarian one, being possible that other hedonic type motives evolve within the consumer decisional process. Services that are primarily consumed for a hedonic type motivation sustain the development of a behavior constructed around the idea of "affective gratification". Thus, the consumption experience regarding these services is not reduced only to a utilitarian aspect, but has a very well highlighted experiential approach (Koenig-Lewis et al., 2018).

For non-traditional consumers, in the case of most service providers, the servicescape can deliver customer delight. That is related to the process of service quality assessment by the consumer that is merely influenced by the contact employee's interaction (functional quality), the expected result of the service encounter (technical quality) and the physical evidence involved in providing the service (Medler-Liraz, 2016; Matute et al., 2018).

In the case of sport events' consumers, the servicescape is a key factor for the development of consumption return. The venue of the sporting event represents a primary variable that can be used to build a higher level of customer service perceptions. The servicescape affects indirectly the re-purchase intention, loyalty, facility image, and word of mouth (Kumar et al., 2017; Hwang \& Lee, 2018). A series of recent studies applied to sports venues have examined how stadium-quality affects the perceptions of servicescape and re-patronage intentions of sports event consumers. Results show that the perceived stadium-quality has a positive role to stimulate arousal and indirectly linked to re-patronage intentions (Ioannou \& Bakirtzoglou, 2016).

Moreover, recent research supports evidence about the fact that is a direct link between sport-scape quality perception and pleasure. Events consumers are supposed to be more influenced by the quality of the facility, their perceptions about it, determining the level of satisfaction related to the quality of the services, and the emotional involvement (Tavares et al., 2018).

Regarding the influence of affect on decision-making, two main theoretical points can be considered: affect evaluation and affect regulation. In light of our paper's main objective, we consider that the mechanism of hedonic consumption induced by the sport events attendance can be explained also with the help of these considerations. Thereby, affect regulation suggests that consumers may use their mood state as information when they evaluate a product while affect regulation implies that emotions generated by a certain product consumption help consumers to modulate or regulate their mood state (López \& De Maya, 2012). So a double effect can be individualized when an individual is exposed to a hedonic type of a product or service: the positive mood that the person already has can be transferred to the evaluation of the product and the ones that already have a bad mood can see the hedonic product as an opportunity to modify and elevate their mood state.

So, if we interpret these mechanisms for the situation of sport events consumption means that if following the participation in the sporting event, the mood is positive, there is the possibility that people tend to consume products that maintain their mood or evaluate different products positively. So, it is clear that products of 
symbolic value in connection with the sporting event concerned will generate hedonic consumption. Similarly, if the outcome of the sporting event produces or contributes to a negative mood, according to the same theories, the consumers in question will tend to develop the same type of consumption that favors the enjoyment and change of the negative state of mind. However, there is a need for caution as to the frequency and intensity with which consumers would adopt hedonic consumption in the context of a negative mood. According to some specialists, there is a tendency that consumers with a negative mood will try to improve their mood but only by engaging in activities that are feasible from this point of view (Tice et al., 2001).

We can assume the situation in which a hypothetical consumer will attend an important sport event. If this person feels already ego involved with a certain product or service, it may be possible that this ego involvement is due to the importance that is given by him to the product or service, the meaning and the importance are given by the pleasure derived from their consumption (in this case we talk about a hedonic value attached) or because that person thinks that the product or service in question says something about him (the symbolic value attached). In this scenario, we can think for example to a sport event-related T-shirt that for sure will have the symbolic value for him and to a restaurant service that will have a hedonic value attached. Because of the ego involvement with the products or services considered, the consumer will care more about his choice of t-shirts or restaurants than other consumers that do not think the products or services considered are important. His intrinsic involvement transforms itself into a concern about purchase and selection, meaning purchase involvement. Thus, we can consider that the special situation in which the consumer is involved (the sport event attendance) can lead to a greater extent of purchase involvement for products or services that have already attached an ego involvement of the individual. If the hedonic value attached to the product or service is already present we can talk about a hedonic type consumption and purchase behavior (Tomaseti \& Ruiz 2009).

Other recent studies highlight a visible connection between the events' environment and affect. A particular atmosphere around an event has more value for consumers if we can talk about an emotional burden associated with it (Pawlowski et al., 2018). Among the factors that can influence the customer experience, we can find a lot of uncontrollable and controllable factors alike. Such examples can be the weather and the team's performance for the unexpected elements and waiting time in the account of controllable service variables. A full body of research sustains the idea that perception about waiting time is for sure an antecedent for the perception about the service quality as delays are impacting on service perception (Keshavarz \& Jamshidi, 2018; Chien \& Lin, 2015). Certainly, waiting for time assessments made by the sport event consumer is augmented by his emotional pressure associated with the hedonic consumption of the game.

In the light of sport events consumption, another factor that is influencing behavior is the "enduring involvement". As we stated earlier, enduring involvement is based on experience, stored in the long-term memory, and stimulated by the degree in which the consumer is ready to give enough meaning to a certain purchase (Sato et al., 2016; Carlson et al., 2015)

If we talk about a high degree of previous involvement for the consumer it is possible to be linked with the self-image and other personal values. In the case of sport events, the core customer base is made of the persons that see and declare themselves as being highly involved in the event-pretty much similar to a certain super-fans or fans for life. The super-fans are building the foundation for season ticket holders and fan clubs. Being caught in the stream of positive emotions elicited by the event encounter, the super-fans will be also more excited about the servicescape (Mutz \& Gerke, 2018).

These emotions are amplified in the case of fans as they are identifying themselves more easily with the team. If we talk about sports team fan identification it can be considered that personal commitment, the perceived connectedness and emotional involvement which a consumer may have with the team, are in such a way that the team's failings and achievements are experienced as one's own (Agha \& Tyler, 2017; Doyle et al., 2017). In the context of out-of-home media reception, consuming a sporting event can contribute to the intensification of emotional aspects of entertainment and the escape from daily life routine. Feelings toward companionship, group affiliation are also amplified, individual identification with the event and membership with the group were intensified through sensory stimulation and emotional activation (Cummins \& Berke, 2017). Thus, the constructs of entertainment and community prestige have positive effects on customers' behavioral intentions making possible an attitude that favors the hedonic consumption of products even after the sporting event. Consumption of sport event media contributes directly to the positive state of mind of consumers, thereby fulfilling the hedonic, eudemonic, and social needs. During this type of event consumption, hedonic, eudemonic, and social values are experienced by consumers taking account of the intensity of the team-spectator relationship and media consumption setting (Kim et al., 2017; Rego-Fagerlande, 2018). 


\section{Method}

The method of research used is an adaptation of the meta-synthesis regarding literature in the field. The meta-synthesis is a more hermeneutic approach that has the goal to understand and explain phenomena (Walsh \& Downe, 2005). Meta-synthesis is also a distinct endeavor compared with the systematic review. The latter is comparing quantitative research and may include statistical analysis of the pooled results from the sources analyzed.

To develop the meta-synthesis, we took into consideration the analysis of the Web of Science database indexed articles. When selecting these articles, the actual insights/results of the research conducted and the relevance of the required variables were considered. In this context, the final number of analyzed articles that can be found within the meta-synthesis framework and the corresponding table is of 45 Web of Science database indexed articles.

The results are suggesting the existence of a causal type relationship between considered variables within the meta-synthesis: motivation for sport events attendance, customer involvement in sport events consumption, propensity over hedonic consumption during, and post sport events attendance. The latter can be analyzed in terms of the differentiation between the hedonic type consumption of the sporting event itself and post-event hedonic type consumption behavior towards other products and services.

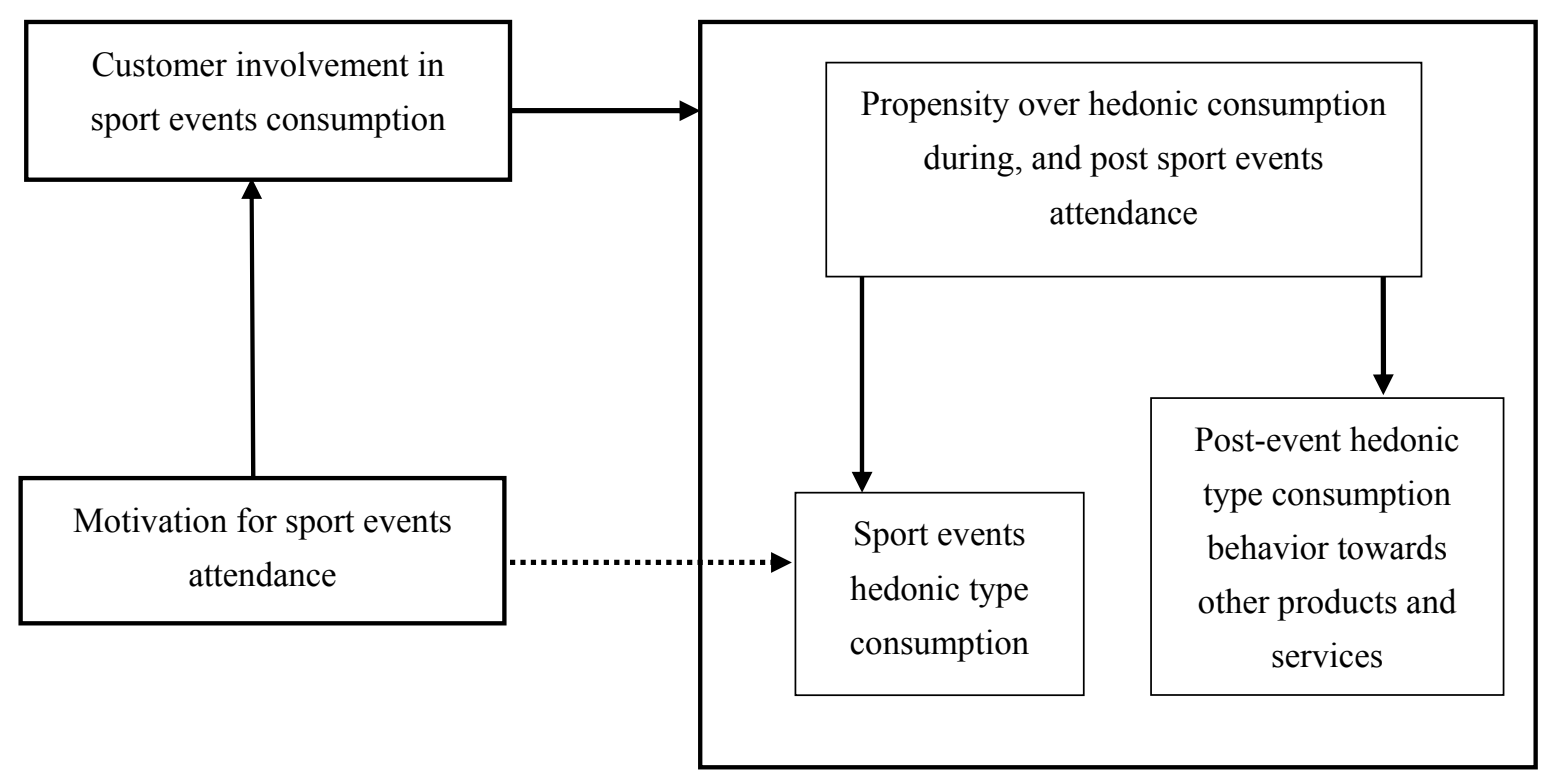

Figure 1. Meta-synthesis framework

The motivation for sport events attendance directly influences customer involvement in sport events consumption, as motivation is one of the preeminent antecedents for involvement. Also, motivation for sport events is relying in general on hedonic type motives that can lead to sport events hedonic type consumption.

Customer involvement in sport events consumption will directly influence propensity over hedonic consumption during and post sport events attendance. This type of hedonic consumption comprises at the same time the hedonic consumption of the event itself and post-event hedonic type consumption behavior towards other products and services.

The variables proposed in the meta-synthesis framework are explained along with relationships where it was the case, within the table below. 
Table 1. Main elements of revised articles

\begin{tabular}{|c|c|c|}
\hline $\begin{array}{l}\text { Main variable } \\
\text { approach }\end{array}$ & Relationship & Explanations \\
\hline \multirow[t]{2}{*}{$\begin{array}{l}\text { Motivation for } \\
\text { sport event } \\
\text { attendance }\end{array}$} & Motivation - involvement & $\begin{array}{l}\text { Motivation is considered the most important } \\
\text { psychological antecedents for customer involvement. } \\
\text { Individual motives and identification are at the core of } \\
\text { socio-psychological dimension of the motivation: } \\
\text { consumption satisfaction, involvement, commitment, } \\
\text { marketing strategy, entertainment, support for players' } \\
\text { league, quality of play, players themselves, players } \\
\text { serving as models, entertainment value associated with } \\
\text { games, beneficial environment, traditional style of play. } \\
\text { Besides hedonic type consumption motives, the Sport } \\
\text { Interest Inventory model is assessing the motives } \\
\text { regarding spectator's attendance to a sporting event: } \\
\text { drama, vicarious achievement, aesthetics, the interest in } \\
\text { connection with the team, certain individual players, the } \\
\text { game itself, a manifestation of national pride feeling, } \\
\text { excitement, perceived social opportunities. }\end{array}$ \\
\hline & Motivation - involvement & $\begin{array}{l}\text { Motivation based on both the perception and interest of } \\
\text { individuals. }\end{array}$ \\
\hline
\end{tabular}

Customer

involvement
Multiple facets concept that can overcome different angles of approach specific to each individual. Involvement has a multidimensional nature.

Involvement - motivational state

Enduring involvement - the propensity for hedonic type consumption

Involvement - hedonic type consumption

Enduring involvement hedonic consumption motives Involvement - behavioral loyalty
Association with motivational state of interest or attraction toward a product/service, activity. Attraction, centrality, and self-expression are essential in the recreational environment.

Situational involvement can change because of the different attributes of the events.

The relationship between products or services and the consumption occasion determine the situational involvement and enduring involvement.

Situational involvement is highlighted when the perceived risk for a certain consumption situation is higher.

Enduring involvement is related to products or services representative for the main values, ego, and personality of people.

Rational and emotional involvement is highlighted, the personal nature of ego-involvement (emotional one) is preeminent.

The main antecedents to involvement are highlighted: product perceived importance, product purchase perceived risk (the importance given to the choice of an inadequate product), the symbolic value of the product, and the hedonic value of the product (ability to provide pleasure/affect).

Enduring event involvement has an important relative effect on future intentions towards the event.

Enduring involvement emphasizes past experience, gives meaning to a certain consumption occasion, highlight the hedonic motives.

Involvement can have an effect mediated by psychological commitment and resistance to change for behavioral loyalty in a professional sports context.
Representative studies

Morris et al., (2018)

Kirkup \& Sutherland, (2017)

Ga-Bin \& Hyung, (2018);

Funk et al., (2002)

Brown et al., (2016); Inoue et al., (2017); Kirkup \&

Sutherland, (2017)

Laurent \& Kapferer, (1985)

Chang \& Gibson, (2015); Dwivedi, (2015); Kim et al., (2015); Seabra et al., (2016); Pansari \& Kumar, (2017)

Nisar et al., (2018)

Tachis \& Tzetzis, (2015); Funk et al., (2016)

Cheng et al., (2015)

Chun \& Lee, (2016); Ko et al., (2017); Zatori et al., (2018)

Whang et al., (2016); Cheng et al., (2016); Pan et al., (2018)

Forgas-Coll et al., (2017); Sato et al., (2018)

Park et al., (2015)

Harrigan et al., (2018)

Carlson et al., (2015)

Sato et al., (2016)

Bee \& Havitz, (2010) 
Involvement - servicescape of sporting events

Travel motives - sport event involvement - event loyalty Fan attraction and involvement - behavioral loyalty

Propensity over hedonic consumption during and post sport events attendance
Hedonic experiences overall game satisfaction

High involvement is correlated with hedonic consumption and attitude toward sport events

Hedonic consumption group norms Hedonic consumption value co-creation within sport events context Hedonic emotions - fan social experience - game satisfaction - future intention to attend a game Hedonic consumption outcomes - the quality of life

Needs for hedonic outcomes as arousal - sport spectating involvement

Consumer motivation hedonic-utilitarian correlation product features Hedonic type consumption features of game experience - post-event consumption of merchandize

Favorable perceptions upon other sport event participants positive influence on-site spending Event-scape - hedonic outcomes - satisfaction Propensity over hedonic consumption during sport events - post-event hedonic type consumption Experiential approach sport event evaluation decision evaluation decisions.
Enduring involvement has an important role as an independent variable that can influence perceptions over servicescape into the context of hedonic services sports activities.

Sport event involvement fully mediates between travel motives and event loyalty.

Fan attraction and involvement influence behavioral loyalty for the event mediated by psychological commitment and resistance to change.

The majority of services are related to affective gratification, thus a hedonic type of motivation.

Loyal sport consumers perceive a high degree of positive emotions towards the sporting event and the servicescape altogether.

Hightower et al., (2002)

Wong \& Tang, (2016)

Bee \& Havitz, (2010)

Koenig-Lewis et al., (2018)

Mutz \& Gerke (2018)

Yoshida \& James, (2010)

Hedonic experiences (sense of entertainment and drama) are a part of the core product of sport events services and influence overall game satisfaction.

Hedonic factors are an important outcome of sport events consumption.

The individual hedonic state is an important determinant of sport consumer behavior.

Hedonic consumption increases the influence of group norms on consumer loyalty.

The value attached to sport events is derived from hedonic components like atmosphere, fun, and entertainment.

Hedonic outcomes of sport events influence media consumption experiences.

Hedonic outcomes of sport event consumption are Theodorakis et al., (2019) influencing perceptions regarding consumers' quality of life.

Hedonic consumption as spectatorship is related to

Ko et al., (2017) fantasy and emotive aspects of the consumption experience.

In a recreational motivation setting (characteristic for sport post-event mood) consumers adopt a hedonic attitude and focus seeking entertainment. Ritual fan behavior during sport events positively influences post-event merchandize expenditure.

Favorable perceptions upon other consumers within the sporting event develop hedonic outcomes.

Event-scape has a positive influence on satisfaction Carneiro et al., (2019) mediated by hedonic type emotions - pleasure. Need fulfillment has a positive effect on short term wellbeing after sport event consumption.

Vieira et al., (2018)

McDonald \& Karg, (2014)

Uhrich \& Benkenstein, (2012)

Hedonic and utilitarian attitudes are used for sport event

Yazıc1 et al., (2017) 


\section{Discussion}

Our findings bring a fresh new insight regarding consumer emotional involvement particularly analyzed within the sport events field, suggesting that there is a direct link between consumption behavior, intentions, attitude, and involvement. The main gaps and problems identified by the earlier analysis cover issues related to emotional involvement in consumption, motivations related to sport events consumption, and propensity over hedonic consumption during sport events attendance. The topics summarized in the previous sections of this article indicate that an individual involved in sport experience as a spectator or a participant is experiencing strong emotional states like suspense, arousal, or excitement as a defining characteristic of it (Lee et al., 2018). Therefore, it becomes obvious that emotion has the role of a strong affective reaction usually associated with sport events consumption. There are different affective outcomes of the direct viewing of sports, amongst them self-esteem, good mood, and physiological arousal being recorded (Kwak et al., 2011). So it can be suggested that emotions seen as interpersonal factors represent a real trigger for motivating people in the direction of identifying a closer relationship with the source of their consumption behavior. Therefore, emotions are stimulating approach/avoidance tendencies within the consumption behavior, sports team-related products being often purchased for their symbolic meaning. More than that, in the context of sport events consumption, the main motivation is built upon the self-actualization of emotions and the meaning brought to life by these.

The inferences of the ideas summarized in the previous sections of this article indicate that involvement considered a multidimensional construct is related to emotions and factors affecting the behavior. One of the most important aspects refers to the fact that in the case of sport events, there are plenty of variables that are defining the sport events services variability — one of them being team performance. The performance can vary from event to event, season to season, or even within a single event. Studies have shown that emotional reactions and enjoyment of fans are depending also on team performance variability (Jang et al., 2018).

Affective evaluation theories portray the idea that individuals are making choices, actions, and evaluations in the light of emotions that is characterizing their inner-self for a particular moment in time. People, when are experiencing pleasure, start a mechanism of conservation of the psychological and emotional state, having a behavior-oriented mood (Schramm \& Knoll, 2017). Possible future research can be aimed at analyzing both high and low committed consumers to see if any modifications of their level of fanship can induce another emotion-behavior response.

Future research should also focus on the degree in which sport events consumers manifest a special tendency at the level of their consumption behavior regarding different brands and types of additional products and services, during the involvement within the sporting event in which they are participating. New additional research is needed to see if when a sporting event is occurring and consumers that are participating are having a well-defined hedonic consumption orientation, they are manifesting the same level of propensity over other than event sponsors products hedonic consumption, outside of the event location. The social and economic implications of such a consumption orientation are multiple and deserve also another distinct research line. As previous research has shown that it is possible to discover psychological principles by analyzing large data sets (big data) as a viable alternative to specialized psychological experiments (Goldstone \& Lupyan, 2016), we can conclude that future developments on the subject should be grounded on the results of empirical research aiming to gather large data sets describing the consumption patterns of participants in sporting events and analyze these data sets using advanced data mining techniques.

\section{Acknowledgments}

All the authors contributed equally to the study.

\section{References}

Agha, N., \& Tyler, B. D. (2017). An investigation of highly identified fans who bet against their favorite teams. Sport Management Review, 20, 296-308. https://doi.org/10.1016/j.smr.2016.09.004

Albrecht, C. M., Hattula, S., Bornemann, T., \& Hoyer, W. D. (2016). Customer response to interactional service experience: the role of interaction environment. Journal of Service Management, 27, 704-729. https://doi.org/10.1108/JOSM-07-2015-0215

Alonso-Dos-Santos, M., Vveinhardt, J., Calabuig-Moreno, F., \& Montoro-Rios, F. J. (2016). Involvement and image transfer in sports sponsorship. Inzinerine Ekonomika-Engineering Economics, 27, 78-89. https://doi.org/10.5755/j01.ee.27.1.8536

Bee, C. C., \& Havitz, M. E. (2010). Exploring the relationship between involvement, fan attraction, psychological commitment and behavioural loyalty in a sports spectator context. International Journal of 
Sports Marketing \& Sponsorship, 11(2), 140-157. https://doi.org/10.1108/IJSMS-11-02-2010-B004

Brown, G., Smith, A., \& Assaker, G. (2016). Revisiting the host city: an empirical examination of sport involvement, place attachment, event satisfaction and spectator intentions at the London Olympics. Tourism Management, 55, 160-172. https://doi.org/10.1016/j.tourman.2016.02.010

Carlson, J., Rosenberger III, P. J., \& Rahman, M. M. (2015). Cultivating group-oriented travel behaviour to major events: assessing the importance of customer-perceived value, enduring event involvement and attitude towards the host destination. Journal of Marketing Management, 31, 1065-1089. https://doi.org/10.1080/0267257X.2015.1035309

Carneiro, M. J., Eusébio, C., Caldeira, A., \& Santos, A. C. (2019). The influence of eventscape on emotions, satisfaction and loyalty: The case of re-enactment events. International Journal of Hospitality Management, 82, 112-124. https://doi.org/10.1016/j.ijhm.2019.03.025

Chang, S., \& Gibson, H. J. (2015). The relationships between four concepts (involvement, commitment, loyalty, and habit) and consistency in behavior across leisure and tourism. Tourism Management Perspectives, 13, 41-50. https://doi.org/10.1016/j.tmp.2014.11.003

Cheng, T. M., Chang, S. Y., \& Dai, Z. P. (2015). The mediating effect of situation involvement of novelty seeking and satisfaction for Yanshuei Fireworks Festival in Taiwan. International Journal of Culture, Tourism and Hospitality Research, 9, 154-167. https://doi.org/10.1108/IJCTHR-10-2014-0084

Cheng, T. M., Hung, S. H., \& Chen, M. T. (2016). The influence of leisure involvement on flow experience during hiking activity: using psychological commitment as a mediate variable. Asia Pacific Journal of Tourism Research, 21, 1-19. https://doi.org/10.1080/10941665.2014.1002507

Chien, S. Y., \& Lin, Y. T. (2015). The effects of the service environment on perceived waiting time and emotions. Human Factors and Ergonomics in Manufacturing \& Service Industries, 25, 319-328. https://doi.org/10.1002/hfm.20542

Chun, J. W., \& Lee, M. J. (2016). Increasing individuals' involvement and WOM intention on social networking sites: content matters! Computers in Human Behavior, 60, 223-232. https://doi.org/10.1016/j.chb.2016.02.069

Chung, E., Farrelly, F., Beverland, M. B., \& Karpen, I. O. (2018). Loyalty or liability: resolving the consumer fanaticism paradox. Marketing Theory, 18, 3-30. https://doi.org/10.1177/1470593117705696

Cummins, R. G., \& Berke, C. K. (2017). Excitation transfer via instant replay in the microstructure of broadcast sport. International Journal of Sport Communication, 10, 468-486. https://doi.org/10.1123/ijsc.2017-0061

Doyle, J. P., Filo, K., Lock, D., Funk, D. C., \& McDonald, H. (2016). Exploring PERMA in spectator sport: Applying positive psychology to examine the individual-level benefits of sport consumption. Sport Management Review, 19(5), 506-519. https://doi.org/10.1016/j.smr.2016.04.007

Doyle, J. P., Lock, D., Funk, D. C., Filo, K., \& McDonald, H. (2017). I was there from the start': the identity-maintenance strategies used by fans to combat the threat of losing. Sport Management Review, 20, 184-197. https://doi.org/10.1016/j.smr.2016.04.006

Dwivedi, A. (2015). A higher-order model of consumer brand engagement and its impact on loyalty intentions. Journal of Retailing and Consumer Services, 24, 100-109. https://doi.org/10.1016/j.jretconser.2015.02.007

Epuran, G., Gârdan, I. P., Gârdan, D. A., \& Bumbaş, F. (2015). Hedonic value of clothing products. Industria Textila, 66, 164-168.

Fenton, S. A., Duda, J. L., \& Barrett, T. (2016). Optimising physical activity engagement during youth sport: a self-determination theory approach. Journal of Sports Sciences, 34, 1874-1884. https://doi.org/10.1080/02640414.2016.1142104

Forgas-Coll, S., Palau-Saumell, R., Matute, J., \& Tarrega, S. (2017). How do service quality, experiences and enduring involvement influence tourists' behavior? An empirical study in the Picasso and Miro Museums in Barcelona. International Journal of Tourism Research, 19, 246-256. https://doi.org/10.1002/jtr.2107

Funk, D., Lock, D., Karg, A., \& Pritchard, M. (2016). Sport consumer behavior research: improving our game. Journal of Sport Management, 30, 113-116. https://doi.org/10.1123/jsm.2016-0028

Funk, D. C., Mahony, D. F., \& Ridinger, L. L. (2002). Characterizing consumer motivation as individual difference factors: Augmenting the sports interest inventory (SII) to explain level of spectator support. Sport 
Marketing Quarterly, 11(1), 33-43.

Ga-Bin, P., \& Hyung, M. L. (2018). The sequential relationships among uses and gratifications, sport team-fan relationship. team identification, game viewing intentions, and viewing recommendation intentions: An empirical analysis on doosan bears' facebook communication and relational outcomes. Journal of Public Relations, 22, 64-100. https://doi.org/10.15814/jpr.2018.22.2.64

Gârdan, D. A., \& Gârdan, I. P. (2015). Modelling medical services consumers' loyalty in the context of changing consumption behavior. Procedia Economics and Finance, 32, 1027-1034. https://doi.org/10.1016/S2212-5671(15)01564-6

Gerhard, F., De Souza, L. L. F., Peñaloza, V., \& Denegri, M. (2017). Exploring utilitarian and hedonic aspects of consumption at the bottom of pyramid. Revista Brasileira de Marketing, 16, 268-280. https://doi.org/10.5585/remark.v16i3.3517

Geus, S. D., Richards, G., \& Toepoel, V. (2016). Conceptualisation and operationalisation of event and festival experiences: creation of an event experience scale. Scandinavian Journal of Hospitality and Tourism, 16, 274-296. https://doi.org/10.1080/15022250.2015.1101933

Goldstone, R. L., \& Lupyan, G. (2016). Discovering psychological principles by mining naturally occurring data sets. Topics in Cognitive Science, 8, 548-568. https://doi.org/10.1111/tops.12212

Harrigan, P., Evers, U., Miles, M. P., \& Daly, T. (2018). Customer engagement and the relationship between involvement, engagement, self-brand connection and brand usage intent. Journal of Business Research, 88, 388-396. https://doi.org/10.1016/j.jbusres.2017.11.046

Hightower Jr, R., Brady, M. K., \& Baker, T. L. (2002). Investigating the role of the physical environment in hedonic service consumption: an exploratory study of sporting events. Journal of Business Research, 55(9), 697-707. https://doi.org/10.1016/S0148-2963(00)00211-3

Hodges, N. J., Augaitis, L., \& Crocker, P. R. (2016). Sport commitment and deliberate practice among male and female triathletes. International Journal of Sport Psychology, 47, 652-665.

Hong, I. B. (2015). Understanding the consumer's online merchant selection process: the roles of product involvement, perceived risk, and trust expectation. International Journal of Information Management, 35, 322-336. https://doi.org/10.1016/j.ijinfomgt.2015.01.003

Horbel, C., Popp, B., Woratschek, H., \& Wilson, B. (2016). How context shapes value co-creation: Spectator experience of sport events. The Service Industries Journal, 36(11-12), 510-531. https://doi.org/10.1080/02642069.2016.1255730

Hossain, M. T. (2018). How cognitive style influences the mental accounting system: role of analytic versus holistic thinking. Journal of Consumer Research, 45, 615-632. https://doi.org/10.1093/jcr/ucy020

Huang, Z., \& Wang, C. L. (2018). Conspicuous consumption in emerging market: the case of Chinese migrant workers. Journal of Business Research, 86, 366-373. https://doi.org/10.1016/j.jbusres.2017.08.010

Huber, F., Eisele, A., \& Meyer, F. (2018). The role of actual, ideal, and ought self-congruence in the consumption of hedonic versus utilitarian brands. Psychology \& Marketing, 35, 47-63. https://doi.org/10.1002/mar.21070

Hwang, J., \& Lee, K. W. (2018). The antecedents and consequences of golf tournament spectators' memorable brand experiences. Journal of Destination Marketing \& Management, 9, 1-11. https://doi.org/10.1016/j.jdmm.2017.09.001

Inoue, Y., Funk, D. C., \& McDonald, H. (2017). Predicting behavioral loyalty through corporate social responsibility: the mediating role of involvement and commitment. Journal of Business Research, 75, 46-56. https://doi.org/10.1016/j.jbusres.2017.02.005

Ioannou, P., \& Bakirtzoglou, P. (2016). The Relationship between stadium factors on spectators' satisfaction in Greek Soccer Super League. Journal of Human Sport and Exercise, 11, 437-443. https://doi.org/10.14198/jhse.2016.114.04

Jang, E. W., Ko, Y. J., Wann, D., \& Chang, Y. (2017). The relative effects of game outcome and process on fans' media consumption experiences. European Sport Management Quarterly, 17(5), 635-658. https://doi.org/10.1080/16184742.2017.1334683

Jang, W. E., Wann, D. L., \& Ko, Y. J. (2018). Influence of team identification, game outcome, and game process 
on sport consumers' happiness. Sport Management Review, 21, 63-71. https://doi.org/10.1016/j.smr.2017.03.002

Jun, S. P., \& Park, D. H. (2016). Consumer information search behavior and purchasing decisions: empirical evidence from Korea. Technological Forecasting and Social Change, 107, 97-111. https://doi.org/10.1016/j.techfore.2016.03.021

Keshavarz, Y., \& Jamshidi, D. (2018). Service quality evaluation and the mediating role of perceived value and customer satisfaction in customer loyalty. International Journal of Tourism Cities, 4, $220-244$. https://doi.org/10.1108/IJTC-09-2017-0044

Kim, J., \& James, J. D. (2019). Sport and happiness: Understanding the relations among sport consumption activities, long-and short-term subjective well-being, and psychological need fulfillment. Journal of Sport Management, 33(2), 119-132. https://doi.org/10.1123/jsm.2018-0071

Kim, J., Kim, Y., \& Kim, D. (2017). Improving well-being through hedonic, eudaimonic, and social needs fulfillment in sport media consumption. Sport Management Review, 20, 309-321. https://doi.org/10.1016/j.smr.2016.10.001

Kim, Y. H., Duncan, J., \& Chung, B. W. (2015). Involvement, satisfaction, perceived value, and revisit intention: a case study of a food festival. Journal of Culinary Science \& Technology, 13, 133-158. https://doi.org/10.1080/15428052.2014.952482

Kirkup, N., \& Sutherland, M. (2017). Exploring the relationships between motivation, attachment and loyalty within sport event tourism. Current Issues in Tourism, 20, 7-14. https://doi.org/10.1080/13683500.2015.1046819

Ko, Y. J., Chang, Y., Jang, W., Sagas, M., \& Spengler, J.O. (2017). A hierarchical approach for predicting sport consumption behavior: a personality and needs perspective. Journal of Sport Management, 31, 213-228. https://doi.org/10.1123/jsm.2015-0142

Koenig-Lewis, N., Asaad, Y., \& Palmer, A. (2018). Sports events and interaction among spectators: examining antecedents of spectators' value creation. European Sport Management Quarterly, 18, 193-215. https://doi.org/10.1080/16184742.2017.1361459

Kumar, D. S., Purani, K., \& Sahadev, S. (2017). Visual service scape aesthetics and consumer response: a holistic model. Journal of Services Marketing, 31, 556-573. https://doi.org/10.1108/JSM-01-2016-0021

Kwak, D. H., Kim, Y. K., \& Hirt, E. R. (2011). Exploring the role of emotions on sport consumers' behavioral and cognitive responses to marketing stimuli. European Sport Management Quarterly, 11(3), 225-250. https://doi.org/10.1080/16184742.2011.577792

Laud, G., \& Karpen, I. O. (2017). Value co-creation behaviour-role of embeddedness and outcome considerations. Journal of Service Theory and Practice, 27, 778-807. https://doi.org/10.1108/JSTP-04-2016-0069

Laurent, G., \& Kapferer, J. N. (1985). Measuring consumer involvement profiles. Journal of Marketing Research, 22(1), 41-53. https://doi.org/10.2307/3151549

Lee, R., Murphy, J., \& Swilley, E. (2009). The moderating influence of hedonic consumption in an extended theory of planned behaviour. The Service Industries Journal, 29(4), 539-555, https://doi.org/10.1080/02642060802287189

Lee, S., Kim, Y., \& Heere, B. (2018). Sport team emotion: conceptualization, scale development and validation. Sport Management Review, 21, 363-376. https://doi.org/10.1016/j.smr.2017.08.007

López, I. L., \& De Maya, S. R. (2012). When hedonic products help regulate my mood. Marketing Letters, 23(3), 701-717. https://doi.org/10.1007/s11002-012-9172-7

Marriott, H. R., Williams, M. D., \& Dwivedi, Y. K. (2017). What do we know about consumer m-shopping behaviour? International Journal of Retail \& Distribution Management, 45, 568-586. https://doi.org/10.1108/IJRDM-09-2016-0164

Matute, J., Palau-Saumell, R., \& Viglia, G. (2018). Beyond chemistry: the role of employee emotional competence in personalized services. Journal of Services Marketing, 32, 346-359. https://doi.org/10.1108/JSM-05-2017-0161

McDonald, H., \& Karg, A. J. (2014). Managing co-creation in professional sports: The antecedents and consequences of ritualized spectator behavior. Sport Management Review, 17(3), 292-309. 
https://doi.org/10.1016/j.smr.2013.07.004

Medler-Liraz, H. (2016). The role of service relationships in employees' and customers' emotional behavior, and customer-related outcomes. Journal of Services Marketing, 30, 437-448. https://doi.org/10.1108/JSM-05-2014-0156

Morris, E., van Riper, C. J., Kyle, G. T., Wallen, K. E., \& Absher, J. (2018). Accounting for gender in a study of the motivation-involvement relationship. Leisure Sciences, 40, 494-507. https://doi.org/10.1080/01490400.2016.1256799

Mutz, M., \& Gerke, M. (2018). Major sporting events and national identification: the moderating effect of emotional involvement and the role of the media. Communication \& Sport, 6, 605-626. https://doi.org/10.1177/2167479517733447

Nisar, T. M., Prabhakar, G., \& Patil, P. P. (2018). Sports clubs' use of social media to increase spectator interest. International Journal of Information Management, 43, 188-195. https://doi.org/10.1016/j.ijinfomgt.2018.08.003

Nyadzayo, M. W., \& Khajehzadeh, S. (2016). The antecedents of customer loyalty: a moderated mediation model of customer relationship management quality and brand image. Journal of Retailing and Consumer Services, 30, 262-270. https://doi.org/10.1016/j.jretconser.2016.02.002

Okayasu, I., Nogawa, H., \& Morais, D. B. (2010). Resource investments and loyalty to recreational sport tourism event. Journal of Travel \& Tourism Marketing, 27(6), 565-578. https://doi.org/10.1080/10548408.2010.507141

Pan, S. L., Wu, H. C., Morrison, A. M., Huang, M. T., \& Huang, W. S. (2018). The relationships among leisure involvement, organizational commitment and well-being: viewpoints from sport fans in Asia. Sustainability, 10, 1-18. https://doi.org/10.3390/su10030740

Pansari, A., \& Kumar, V. (2017). Customer engagement: the construct, antecedents, and consequences. Journal of the Academy of Marketing Science, 45, 294-311. https://doi.org/10.1007/s11747-016-0485-6

Park, N., Oh, H. S., \& Kang, N. (2015). Effects of ego involvement and social norms on individuals' uploading intention on Wikipedia: a comparative study between The United States and South Korea. Journal of the Association for Information Science and Technology, 66, 1494-1506. https://doi.org/10.1002/asi.23262

Pawlowski, T., Nalbantis, G., \& Coates, D. (2018). Perceived game uncertainty, suspense and the demand for sport. Economic Inquiry, 56, 173-192. https://doi.org/10.1111/ecin.12462

Prayag, G., Hosany, S., Muskat, B., \& Del Chiappa, G. (2017). Understanding the relationships between tourists' emotional experiences, perceived overall image, satisfaction, and intention to recommend. Journal of Travel Research, 56, 41-54. https://doi.org/10.1177/0047287515620567

Rajala, R., Toytari, P., \& Hervonen, T. (2015). Assessing customer-perceived value in industrial service systems. Service Science, 7, 210-226. https://doi.org/10.1287/serv.2015.0108

Raposo, A., Frade, S., Alves, M., \& Marques, J. F. (2018). The neural bases of price estimation: Effects of size and precision of the estimate. Brain and Cognition, 125, 157-164. https://doi.org/10.1016/j.bandc.2018.07.005

Rego-Fagerlande, S. M. (2018). Big sports events in rio de janeiro: their effects on the slums. Bitacora Urbano Territorial, 28, 143-150. https://doi.org/10.15446/bitacora.v28n2.70037

Rocha, C. M., \& Gratao, O. A. (2018). The process toward commitment to running - the role of different motives, involvement, and coaching. Sport Management Review, 21, 459-472. https://doi.org/10.1016/j.smr.2017.10.003

Sato, M., Jordan, J. S., \& Funk, D. C. (2016). A distance-running event and life satisfaction: the mediating roles of involvement. Sport Management Review, 19, 536-549. https://doi.org/10.1016/j.smr.2016.04.001

Sato, M., Jordan, J. S., Funk, D. C., \& Sachs, M. L. (2018). Running involvement and life satisfaction: the role of personality. Journal of Leisure Research, 49, 28-45. https://doi.org/10.1080/00222216.2018.1425051

Schramm, H., \& Knoll, J. (2017). Effects of women's football broadcastings on viewers' moods and judgments: investigating the moderating role of team identification and sex. Communication Research, 44, 54-76. https://doi.org/10.1177/0093650215583894

Seabra, C., Silva, C., Luís Abrantes, J., Vicente, M., \& Herstein, R. (2016). The influence of motivations in 
tourists' involvement. Anatolia, 27, 4-15. https://doi.org/10.1080/13032917.2015.1083204

Shank, D. B., \& Lulham, R. (2017). Products as affective modifiers of identities. Sociological Perspectives, 60, 186-205. https://doi.org/10.1177/0731121416629996

Singh, J. P., Irani, S., Rana, N. P., Dwivedi, Y. K., Saumya, S., \& Roy, P. K. (2017). Predicting the "helpfulness" of online consumer reviews. Journal of Business Research, 70, 346-355. https://doi.org/10.1016/j.jbusres.2016.08.008

Tachis, S., \& Tzetzis, G. (2015). The relationship among fans' involvement, psychological commitment, and loyalty in professional team sports. International Journal of Sport Management, 18, 1-25. https://doi.org/10.5199/ijsmart-1791-874X-18a

Tavares, A. B., Telles, S. D. C., \& Votre, S. J. (2018). The Maracana stadium: a comparative study between fans' social representations about football's old and new place. Movimento, 24, 353-366. https://doi.org/10.22456/1982-8918.75681

Teng, C. C., \& Lu, C. H. (2016). Organic food consumption in Taiwan: motives, involvement, and purchase intention under the moderating role of uncertainty. Appetite, 105, 95-105. https://doi.org/10.1016/j.appet.2016.05.006

Theodorakis, N. D., Kaplanidou, K., Alexandris, K., \& Papadimitriou, D. (2019). From sport event quality to quality of life: The role of satisfaction and purchase happiness. Journal of Convention \& Event Tourism, 20(3), 241-260. https://doi.org/10.1080/15470148.2019.1637805

Tice, D. M., Bratslavsky, E., \& Baumeister, R. F. (2001). Emotional distress regulation takes precedence over impulse control: If you feel bad, do it! Journal of Personality and Social Psychology, 80(1), 53-67. https://doi.org/10.1037//0022-3514.80.1.53

Tomaseti, E., \& Ruiz, S. (2009). The evaluation of new utilitarian and symbolic products: the effect of attribute type and product knowledge. Advances in Consumer Research, 36, 919-921.

Uhrich, S., \& Benkenstein, M. (2012). Physical and social atmospheric effects in hedonic service consumption: customers' roles at sporting events. The Service Industries Journal, 32(11), 1741-1757. https://doi.org/10.1080/02642069.2011.556190

Vegheș, C. (2018). Cultural heritage, sustainable development and inclusive growth: global lessons for the local communities under a marketing approach. European Journal of Sustainable Development, 7, 349-360. https://doi.org/10.14207/ejsd.2018.v7n4p349

Vieira, V., Santini, F. O., \& Araujo, C. F. (2018). A meta-analytic review of hedonic and utilitarian shopping values. Journal of Consumer Marketing, 35(4), 426-437. https://doi.org/10.1108/JCM-08-2016-1914

Walsh, D., \& Downe, S. (2005). Meta-synthesis method for qualitative research: a literature review. Journal of Advanced Nursing, 50, 204-211. https://doi.org/10.1111/j.1365-2648.2005.03380.x

Walther, J. B., Kashian, N., Jang, J. W., Shin, S. Y., Dai, Y., \& Koutamanis, M. (2018). The effect of message persistence and disclosure on liking in computer-mediated communication. Media Psychology, 21, 308-327. https://doi.org/10.1080/15213269.2016.1247718

Whang, H., Yong, S., \& Ko, E. (2016). Pop culture, destination images, and visit intentions: theory and research on travel motivations of Chinese and Russian tourists. Journal of Business Research, 69, 631-664. https://doi.org/10.1016/j.jbusres.2015.06.020

Wong, I. A., \& Tang, S. L. W. (2016). Linking travel motivation and loyalty in sporting events: The mediating roles of event involvement and experience, and the moderating role of spectator type. Journal of Travel \& Tourism Marketing, 33(1), 63-84. https://doi.org/10.1080/10548408.2015.1038417

Yazıcı, T., Kocak, S., \& Altunsöz, I. H. (2017). Examining the effect of experiential marketing on behavioral intentions in a festival with a specific sport event. European Sport Management Quarterly, 17(2), 171-192. https://doi.org/10.1080/16184742.2016.1247903

Yoshida, M., \& James, J. D. (2010). Customer satisfaction with game and service experiences: Antecedents and consequences. Journal of Sport Management, 24(3), 338-361. https://doi.org/10.1123/jsm.24.3.338

Zatori, A., Smith, M. K., \& Puczko, L. (2018). Experience-involvement, memorability and authenticity: the service provider's effect on tourist experience. Tourism Management, 67, 111-126. https://doi.org/10.1016/j.tourman.2017.12.013 
Zheng, X. Y., Baskin, E., \& Peng, S. Q. (2018). Feeling inferior, showing off: the effect of nonmaterial social comparisons on conspicuous consumption. Journal of Business Research, 90, 196-205. https://doi.org/10.1016/j.jbusres.2018.04.041

Zucco, F. D., Rodrigues, L. C., Kock, N., \& Riscarolli, V. (2015). Sports sponsorship: perspectives of involvement, identification and prestige between fans and team. Podium-Sport, Leisure and Tourism Review, 4, 140-152. https://doi.org/10.5585/podium.v4i3.137

\section{Copyrights}

Copyright for this article is retained by the author, with first publication rights granted to the journal.

This is an open-access article distributed under the terms and conditions of the Creative Commons Attribution license (http://creativecommons.org/licenses/by/4.0/). 